\title{
Correction: Development of a systemic lupus erythematosus cardiovascular risk equation
}

Petri MA, Barr E, Magder LS. Development of a systemic lupus erythematosus cardiovascular risk equation. Lupus Science E $\mathcal{E}$ Medicine 2019;6:e000346. doi: 10.1136/ lupus-2019-000346.

The article has been corrected since it was published online. In the Results section (page 4), the third paragraph (column 1) should read as

The HRs in table 4 can be used to calculate the 10-year risk for a patient with any risk factor profile using the formula:

Risk $=1-0.975^{\mathrm{HR}}$

where HR is the hazard ratio for that patient relative to a non-smoking female aged 50 years with systolic blood pressure $=120 \mathrm{~mm} \mathrm{Hg}$, total serum cholesterol exceeding $150 \mathrm{mg} / \mathrm{dL}$, and no diabetes and no SLE risk factors

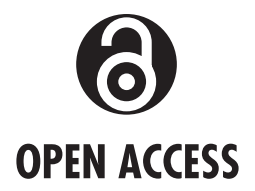

Open access This is an open access article distributed in accordance with the Creative Commons Attribution Non Commercial (CC BY-NC 4.0) license, which permits others to distribute, remix, adapt, build upon this work non-commercially, and license their derivative works on different terms, provided the original work is properly cited, appropriate credit is given, any changes made indicated, and the use is non-commercial. See: http://creativecommons.org/licenses/by-nc/4.0/.

Lupus Sci Med 2020;7:e000346corr1. doi:10.1136/lupus-2019-000346corr1

Check for updates 